\section{Springer Protocols}

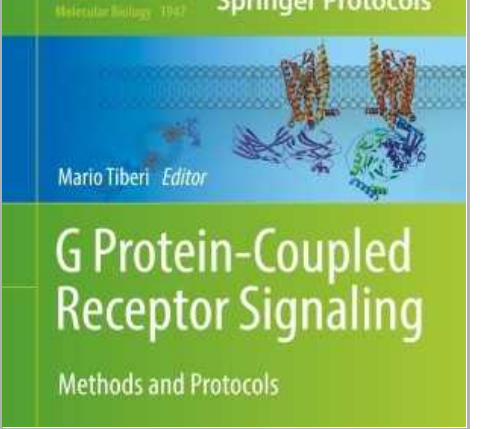

SEP 22, 2021

\section{open ठaccess}

\section{DOI:}

dx.doi.org/10.17504/protocol s.io.bqnumvew

\section{External link:}

https://link.springer.com/proto col/10.1007/978-1-49399121-1_4

\section{Protocol Citation: Anne} Zemella, Theresa Richter, Lena Thoring, Stefan Kubick 2021. Preparation of Enhanced Orthogonal Aminoacyl-tRNA-Synthetase. protocols.io

https://dx.doi.org/10.17504/p rotocols.io.bqnumvew

\section{MANUSCRIPT CITATION:}

Zemella A., Richter T., Thoring L., Kubick S. (2019) A

Combined Cell-Free Protein Synthesis and FluorescenceBased Approach to Investigate GPCR Binding Properties. In: Tiberi M. (eds) G ProteinCoupled Receptor Signaling. Methods in Molecular Biology, vol 1947. Humana Press, New York, NY. https://doi.org/10.1007/9781-4939-9121-1_4

\section{(3) Preparation of Enhanced Orthogonal Aminoacyl-tRNA- Synthetase}

$\rightarrow$ In 1 collection

Anne Zemella ${ }^{1}$, Theresa Richter $^{1}, 2$, Lena Thoring ${ }^{1}$, Stefan Kubick $^{1}$

${ }^{1}$ Cell-free and Cell-based Bioproduction, Fraunhofer Institute for Cell

Therapy and Immunology (IZI), Branch Bioanalytics and Bioprocesses (IZIBB), Potsdam, Germany;

2University of Potsdam, Potsdam, Germany

\section{Springer Nature Books}

Satyavati Kharde

Springer Nature 
License: This is an open access protocol distributed under the terms of the Creative Commons Attribution License, which permits unrestricted use, distribution, and reproduction in any medium, provided the original author and source are credited

Protocol status: Working

Created: Dec 12, 2020

Last Modified: Sep 22, 2021

PROTOCOL integer ID: 45492

Keywords: Cell-free protein synthesis, G protein-coupled receptor, Protein modification, Non-canonical amino acids, Amber suppression, Confocal laser scanning microscopy

\section{ABSTRACT}

This is part 3.1 of the "A Combined Cell-Free Protein Synthesis and Fluorescence-Based Approach to Investigate GPCR Binding Properties" collection of protocols: https://www.protocols.io/view/a-combined-cellfree-protein-synthesis-and-fluores-bqntmven

Collection Abstract: Fluorescent labeling of de novo synthesized proteins is in particular a valuable tool for functional and structural studies of membrane proteins. In this context, we present two methods for the site-specific fluorescent labeling of difficult-to-express membrane proteins in combination with cell-free protein synthesis. The cell-free protein synthesis system is based on Chinese Hamster Ovary Cells $(\mathrm{CHO})$ since this system contains endogenous membrane structures derived from the endoplasmic reticulum. These so-called microsomes enable a direct integration of membrane proteins into a biological membrane. In this protocol the first part describes the fluorescent labeling by using a precharged tRNA, loaded with a fluorescent amino acid. The second part describes the preparation of a modified aminoacyl-tRNA-synthetase and a suppressor tRNA that are applied to the $\mathrm{CHO}$ cell-free system to enable the incorporation of a non-canonical amino acid. The reactive group of the non-canonical amino acid is further coupled to a fluorescent dye. Both methods utilize the amber stop codon suppression technology. The successful fluorescent labeling of the model $G$ protein-coupled receptor adenosine A2A (Adora2a) is analyzed by in-gel-fluorescence, a reporter protein assay, and confocal laser scanning microscopy (CLSM). Moreover, a ligand-dependent conformational change of the fluorescently labeled Adora2a was analyzed by bioluminescence resonance energy transfer (BRET).

For Introduction and Notes, please see: https://www.protocols.io/view/acombined-cell-free-protein-synthesis-and-fluores-bqntmven/guidelines 


\section{MATERIALS}

\subsection{Materials for Preparation of Enhanced Orthogonal Aminoacyl-tRNA- Synthetase}

1. Coding sequence for the modified tyrosyl-tRNA-synthetase (eAzFRS, including the mutations Thr37, Ser182, Ala183, and Arg265 [11, 12] and a C-terminal Strep-Tag) from E.coli.

2. E.coliexpression system (RTS 500 E.coliHY Kit, biotechrabbit).

3. $100 \mathrm{mM}$ Isopropyl $\beta$-D-1-thiogalactopyranoside (IPTG)

4. Gravity flow Strep-Tactin ${ }^{\circledR}$ superflow mini-column $(0.2 \mathrm{ml})$.

5. Strep-Tactin ${ }^{\circledR}$ Purification Buffer Set: $10 \times$ Washing Buffer (1 M Tris-Cl, pH 8.0, 1.5 $\mathrm{M} \mathrm{NaCl}, 10 \mathrm{mM}$ EDTA), 10x Elution Buffer (1 M Tris-Cl, pH 8.0, 1.5 M NaCl, 10 mM EDTA, 25 mM Desthiobiotin) and 10x Regeneration Buffer (1 M Tris-Cl, 1.5 M $\mathrm{NaCl}, 10$ mM EDTA, 10 mM HABA (hydroxyl-azophenyl-benzoic acid)).

6. Zeba ${ }^{\mathrm{TM}}$ Spin Desalting Columns (7 K MWCO, $\left.0.5 \mathrm{ml}\right)$.

7. Amicon ${ }^{\circledR}$ Ultra Centrifugal Filters $(10 \mathrm{~K}$ device, $0.5 \mathrm{ml})$.

8. Synthetase storage buffer: $50 \mathrm{mM} \mathrm{HEPES} \mathrm{pH} \mathrm{7.6,} 10 \mathrm{mM} \mathrm{KOAc,} 1 \mathrm{mM} \mathrm{MgCl}$, 4 mM DTT.

9. Thermomixer with a microtiter plate adapter and a RTS 500 adapter.

\section{SAFETY WARNINGS}

(1) For hazard information and safety warnings, please refer to the SDS (Safety Data Sheet).

\subsection{Preparation of Enhanced Orthogonal Aminoacyl-tRNA $20 \mathrm{~h}$}

1 For prokaryotic cell-free synthesis, the eAzFRS gene should be cloned into a vector containing a T7 promotor, ribosomal binding site, and T7 terminator such as pIX3.0, pIVEX2.3d, and pIVEX2.4d vectors or alternatively containing a T5 promotor such as PQE2 vectors as used in this protocol. eAzFRS is synthesized in a cell-free system using an $E$. colilysate in a dialysis mode. A typical $1.1 \mathrm{ml}$ reaction is composed of \ $0.525 \mathrm{~mL}$ E.coli lysate, \ $0.225 \mathrm{~mL}$ reaction mix ,

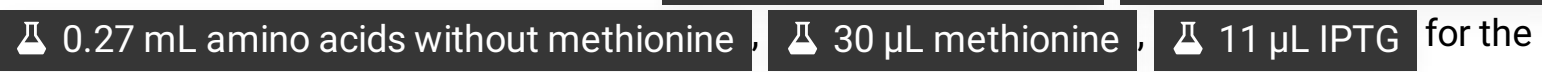
induction of the protein expression PQE2 vector, \ $39 \mu \mathrm{L}$ template containing

\section{I $110 \mu \mathrm{g}$ plasmid DNA}

2 The surrounding feeding mixture contains \& $7990 \mu \mathrm{L}$ feeding mix , \ $110 \mu \mathrm{L}$ IPTG ,

\ $2650 \mu \mathrm{L}$ amino acids without methionine and $\triangle 300 \mu \mathrm{L}$ methionine (see Note 2). 
3 Fill the reaction solution into the reaction compartment (marked through the red lid).

4 Fill the feeding mix into the feeding chamber (marked through the colorless lid).

5 Insert the prepared chamber into the RTS 500 adapter in a thermomixer. The reaction time is

(3) 20:00:00 at $80^{\circ} \mathrm{C}$ and a shaking speed of (5) $900 \mathrm{rpm}$

6 For the separation of aggregated proteins from soluble eAzFRS a centrifugation step at $16000 \times \mathrm{g}, 4^{\circ} \mathrm{C}, 00: 10: 00$ is recommended.

7 Equilibrate two Strep-Tactin columns with $8400 \mu \mathrm{L} 10 \times$ washing buffer and add \ $500 \mu \mathrm{L}$ supernatant of the cell-free reaction to each column.

8 After the supernatant has completely entered the column, wash each column $5 \times$ with \ $200 \mu \mathrm{L}$ washing buffer (see Note 3).

9 Elute the protein $6 \times$ with $8100 \mu \mathrm{L}$ elution buffer and collect the fractions.

10 Elution fractions containing the target protein are pooled. 
11 Regenerate the column with $3 \times$ \& $1 \mathrm{~mL} 1 \times$ regeneration buffer and remove the regeneration buffer $2 \times$ with $\triangle 800 \mu \mathrm{L} 1 \times$ washing buffer . Store the column in $\triangle 2 \mathrm{~mL}$ washing buffer at $8^{\circ} 4^{\circ} \mathrm{C}$

12 The combined elution fractions are applied to Zeba ${ }^{\text {TM }}$ Spin Desalting Columns to exchange the elution buffer of the strep-tag purification to a synthetase storage buffer. Therefore, remove the storage solution of the Zeba ${ }^{\text {TM }}$ Spin Desalting Column by centrifugation at $\because: 1500 \times$ g, 00:01:00 Add $\triangle 300 \mu \mathrm{L}$ synthetase storage buffer to the resin bed and centrifuge at $\therefore 1500 \times \mathrm{g}, 00: 01: 00$. Repeat this step 2x.

Place the column in a new collection tube and apply $\Delta 100 \mu \mathrm{L}$ pooled synthetase solution to each column. Centrifuge at $\because 2000 \times \mathrm{g}, 00: 02: 00$ and collect the synthetase.

13 The concentration of the synthetase can be performed with Amicon ${ }^{\circledR}$ Ultra Centrifugal Filters. Add up to $\triangle 500 \mu \mathrm{L}$ synthetase solution to the concentrator and centrifuge at $\therefore 14000 \times \mathrm{g}, 4^{\circ} \mathrm{C}, 00: 10: 00$. Collect the concentrated sample and determine the concentration by NanoDrop measurement using the molecular mass $(48.6 \mathrm{kDa})$ and the extinction coefficient (54.3) (see Note 4).

14 The synthetase can be stored at $8^{\circ}-80^{\circ} \mathrm{C}$ after shock freezing in liquid nitrogen. 